\title{
Histochemical similarities between newborn and leukaemic myeloid cells and their possible significance
}

\author{
PAUL L. WOLF, BORIS SILBERBERG, SAMUEL ALBERT, \\ JEROME HORWITZ, AND ELISABETH VON DER MUEHLL \\ From the Department of Pathology, Stanford University Medical Center, \\ Wayne State University School of Medicine, Detroit General Hospital, Hutzel Hospital, \\ and Detroit Institute of Cancer Research, USA
}

SYNOPSIS The neutrophilic alkaline phosphatase activity of 40 newborns was determined and found to be frequently raised, similarly to a leukaemoid reaction. The newborn neutrophil has strong alkaline phosphatase activity and is unlike the myeloid leukaemia cell which has no alkaline phos? phatase activity.

We have recently been interested in investigating various enzyme activities in leukaemic cells. It has been established that neutrophils in chronic myeloid leukaemia have decreased or absent alkaline phosphatase activity (Kaplow, 1955; Wiltshaw and Maloney, 1955). Furthermore, studies have demonstrated that in neutrophils the alkaline phosphatase activity is raised in leukaemoid states due to various aetiologies, polycythaemia rubra vera, and in extraand intrauterine pregnancy.

It is possible that the adult leukaemic myeloid cell may represent an immature cell such as is found in newborn infants. In this study, the problem was to ascertain if the newborn neutrophil possessed alkaline phosphatase activity.

\section{METHODS AND MATERIALS}

We studied 40 newborns (first week of life). The infants were equally divided into male and female and Caucasian and Negro groups. The Kaplow (1955) modification of the Gomori alkaline phosphatase method was utilized. The staining method was:

1 Fix air-dried peripheral blood smears in $95 \%$ alcohol for one minute.

2 Incubate for two hours at $37^{\circ} \mathrm{C}$ in barbital buffered medium containing beta-glycerophosphate, $\mathrm{CaCl}_{2}$ and $\mathrm{MgSO}_{4}$ at $p \mathrm{H} \mathbf{9 \cdot 2}$.

3 Wash in dilute $\mathrm{CaCl}_{2}$ solution.

4 Immerse in $1.5 \%$ cobalt acetate for five minutes.

5 Wash in tap water.

6 Place in dilute ammonium sulphide for five minutes $\left(1.5 \% \mathrm{NH}_{4} \mathrm{~S}\right)$.

'Present address: Clinical Laboratory, Stanford University Medical Center, Stanford, California 94305.

Received for publication 31 October 1968.
7 Wash in tap water. Allow to dry.

8 Counterstain with Leishman's or Wright's stain.

For the scoring technique we counted 100 consecutive neutrophilic granulocytes, rating them from 0 to $4+$ o o the basis of the intensity and appearance of the precip tated dye in the cyloplasm as follows: $0=$ colourlesson $1+=$ diffuse pale brown, no granules; $2+=$ brow with or without occasional clumps of brown-black precipitate; $3+=$ brownish-black, unevenly distribute granular precipitate; $4+=$ uniform deep black granular? precipitate.

The sum of the ratings of 100 cells is considered the 'score' for a particular smear. For purposes of compari son in scoring, select areas of similar cell thickness preferably where the erythrocytes just touch.

Normal infants have given scores ranging from to 76 with an average of 22 . Infections give much highep values. In granulocytic leukaemia, the granulocytes are negative.

\section{RESULTS}

The results indicated that all newborns had neutro philic alkaline phosphatase activity (Tables I and II)? Female and Negro newborns had higher activity Many had markedly raised activity similar to leukaemoid condition. Furthermore, two populao tions of neutrophils were seen in many patientso One group of cells showed moderate activity and the other groups none (Table III).

Those infants who were jaundiced, secondary too physiological jaundice or erythroblastosis foetaliso had scores in the lower range of normal.

\section{DISCUSSION}

This investigation has demonstrated that the news born neutrophil has alkaline phosphatase activity 
TABLE I

FEMALE NEWBORNS

\begin{tabular}{cl} 
Negro & Caucasian \\
\hline 156 & 208 \\
119 & 119 \\
14 & 182 \\
27 & 108 \\
126 & 19 \\
170 & 105 \\
119 & 175 \\
170 & 100 \\
98 & 103 \\
69 & 101
\end{tabular}

TABLE II

MALE NEWBORNS

\begin{tabular}{cc} 
Negro & Caucasian \\
\hline 24 & 134 \\
92 & 30 \\
98 & 90 \\
60 & 89 \\
86 & 11 \\
125 & 64 \\
170 & 29 \\
38 & 159 \\
131 & 83 \\
146 & 50
\end{tabular}

TABLE III

PATIENTS' SCORES SUGGESTIVE OF TWO POPULATIONS OF NEUTROPHILS

\begin{tabular}{lrrrrrr} 
& \multicolumn{6}{l}{ Score } \\
\cline { 2 - 7 } Patient & 0 & + & ++ & +++ & ++++ & Total \\
\hline F/W & 34 & 36 & 32 & 0 & 0 & 100 \\
F/W & 31 & 35 & 34 & 0 & 0 & 103 \\
F/N & 19 & 8 & 74 & 0 & 0 & 156 \\
F/N & 8 & 14 & 78 & 0 & 0 & 170 \\
F/N & 41 & 22 & 38 & 0 & 0 & 98
\end{tabular}

In fact, a large number of newborns had alkaline phosphatase scores which are leukaemoid in type. However, in several newborns who had leukaemoid scores, two populations of neutrophils were delineated with this enzyme histochemical technique. One population had alkaline phosphatase activity and another had no activity as is present in chronic myelogenous leukaemia. The significance and cause for the existence of this population without alkaline phosphatase activity is not known. One might specu- late that a proliferation of this type of cell is involved in chronic myelogenous leukaemia. Further studies are now in progress to assess further this finding utilizing a computer method which we recently employed to assess cellular populations in cases of megaloblastic anaemia and chronic lymphatic leukaemia (Albert, Powsner, Berman, and Wolf, 1966; Albert, Moore, Potter, Arnold, and Wolf, 1967).

The reason for the presence of the leukaemoid-type scores in a large proportion of the infants is not wholly apparent. It may be related to physiological leucocytosis or stress of birth.

The higher scores were found in infants who had traumatic births, eg, prolonged labour or umbilical cords around the neck at birth; circumcision led to leukaemoid scores. Jaundice caused a reduction in the leucocyte alkaline phosphatase. The presence of a raised plasma haemoglobin level, as in intravascular haemolysis, inhibits alkaline phosphatase of granulocytes. We are now evaluating a new indoxyl-alkaline phosphatase substrate (Wolf, Horwitz, Vazquez, and von der Muehll, 1969). This substrate was recently utilized for enzyme histochemistry of alkaline and acid phosphatase in tissues and sera (Wolf, Horwitz, Vazquez, Chua, Pak, and von der Muehll, 1967; Epstein, Wolf, Horwitz, and Zak, 1967).

This work was supported by grants from the US Public Health Service (research grant CA-02624), the Michigan Cancer Foundation, the Detroit General Hospital Research Corporation, and the Newaygo County Cancer Society. We thank Miss Pat Warzocha for secretarial assistance.

\section{REFERENCES}

Albert, S., Moore, G. W., Potter, R., Arnold, W. J., and Wolf, P. L. (1967). Nature (Lond.), 216, 491.

—, Powsner, E. R., Berman, L., and Wolf, P. L. (1966). Ibid., 212, 825.

Epstein, E., Wolf, P. L., Horwitz, J. P., and Zak, B. (1967). Amer. J. clin. Path., 48, 530.

Kaplow, L. S. (1955). Blood, 10, 1023.

Wiltshaw, E., and Moloney, W. C. (1955). Ibid., 10, 1120.

Wolf, P. L., Horwitz, J. P., Vazquez, J., Chua, J., Pak, M. S. Y., and von der Muehll, E. (1967). Experientia (Basel), 23, 183.

$-, \frac{1}{\text { Vol }}, \frac{1}{13}$, and von der Muehll, E. (1968). Enzymologia, 